\title{
In vitro antiviral activity of fifteen plant extracts against avian infectious bronchitis virus
}

\author{
Raimundas Lelešius ${ }^{1,2^{*}}$ (D) Agneta Karpovaitè ${ }^{2}$, Rūta Mickienè ${ }^{3}$, Tomas Drevinskas ${ }^{3}$, Nicola Tiso ${ }^{3}$, Ona Ragažinskiené ${ }^{4}$, \\ Loreta Kubiliené ${ }^{5}$, Audrius Maruška ${ }^{3}$ and Algirdas Šalomskas²
}

\begin{abstract}
Background: Avian infectious bronchitis (IB) is a disease that can result in huge economic losses in the poultry industry. The high level of mutations of the IB virus (IBV) leads to the emergence of new serotypes and genotypes, and limits the efficacy of routine prevention. Medicinal plants, or substances derived from them, are being tested as options in the prevention of infectious diseases such as IB in many countries. The objective of this study was to investigate extracts of 15 selected medicinal plants for anti-IBV activity.

Results: Extracts of S. montana, O. vulgare, M. piperita, M. officinalis, T. vulgaris, H. officinalis, S. officinalis and D. canadense showed anti-IBV activity prior to and during infection, while S. montana showed activity prior to and after infection. $M$. piperita, O. vulgare and T. vulgaris extracts had $>60 \mathrm{SI}$. In further studies no virus plaques (plaque reduction rate 100\%) or cytopathogenic effect (decrease of $\mathrm{TCID}_{50}$ from 2.0 to $5.0 \log _{10}$ ) were detected after IBV treatment with extracts of $M$. piperita, D. canadense and T. vulgaris at concentrations of extracts $\geq 0.25$ cytotoxic concentration $\left(C_{50}\right)(P<0.05)$. Both PFU number and $\mathrm{TCID}_{50}$ increased after the use of M. piperita, D. canadense, T. vulgaris and M. officinalis extracts, the concentrations of which were $0.125 C_{50}$ and $0.25 C_{50}(P<0.05)$. Real-time PCR detected IBV RNA after treatment with all plant extracts using concentrations of 1:2 $\mathrm{CC}_{50}, 1: 4 \mathrm{CC}_{50}$ and 1:8 $\mathrm{CC}_{50}$. Delta cycle threshold $(\mathrm{Ct})$ values decreased significantly comparing $C t$ values of 1:2 $C C_{50}$ and 1:8 $C C_{50}$ dilutions $(P<0.05)$.
\end{abstract}

Conclusions: Many extracts of plants acted against IBV prior to and during infection, but the most effective were those of M. piperita, T. vulgaris and D. canadense.

Keywords: Avian infectious bronchitis, Plant extracts, Antiviral activity

\section{Background}

IB is a highly contagious respiratory and occasionally urogenital disease in chickens [1]. IBV affects the upper respiratory tract and reduces egg production [2]. It is a coronavirus that belongs to the Coronaviridae family. IBV is an enveloped virus with a single-stranded positive-sense linear RNA molecule (approximately $27.6 \mathrm{~kb}$ in size) [3].

IB has a wide geographical distribution and is diagnosed worldwide [1]. IB outbreaks continuously and results in economic losses in the poultry industry. So far vaccination

\footnotetext{
* Correspondence: raimundas.lelesius@|smuni.lt

${ }^{1}$ Institute of Microbiology and Virology, Veterinary Faculty, Lithuanian

University of Health Sciences, Kaunas, Lithuania

${ }^{2}$ Department of Veterinary Pathobiology, Veterinary Faculty, Lithuanian

University of Health Sciences, Kaunas, Lithuania

Full list of author information is available at the end of the article
}

using inactivated or live vaccines [4] is regarded as the main method of prevention, but it is not having the desired effect [5-7]. The high level of mutations of IBV [8] leads to the emergence of new serotypes and genotypes, and limits the efficacy of routine prevention.

Biological products derived from plants are used in medicine for different pharmacological reasons, including the treatment of infectious and non-infectious diseases [9, 10]. This class of antimicrobial plants is acknowledged and well investigated, and classes of active compounds have already been identified $[11,12]$. The investigation of antiviral substances derived from plants is insufficient in comparison with the investigation of antimicrobial properties. Fortunately, several experiments have shown that plants have positive antiviral activity in vitro and in vivo

(c) The Author(s). 2019 Open Access This article is distributed under the terms of the Creative Commons Attribution 4.0 International License (http://creativecommons.org/licenses/by/4.0/), which permits unrestricted use, distribution, and reproduction in any medium, provided you give appropriate credit to the original author(s) and the source, provide a link to the Creative Commons license, and indicate if changes were made. The Creative Commons Public Domain Dedication waiver (http://creativecommons.org/publicdomain/zero/1.0/) applies to the data made available in this article, unless otherwise stated. 
[13]. However, the same plants can have different antiviral activity against RNA or DNA viruses, either enveloped or non-enveloped, and even against different types or strains of a virus $[14,15]$.

A number of scientific publications have encouraged the use of polyphenolic compounds in the treatment and prophylaxis of chronic diseases [16]. The mixture of the geometric isomers and enantiomers of rosmarinic acid is accumulating in the families Lamiaceae Lindl, Asteraceae Bercht. \& J.Presl $[17,18]$. Most large quantities of rosmarinic acid have been determined in the genus of plants such as Salvia L., Perilla L. Melissa L. and Echinacea Moench. Rosmarinic acid has antioxidative, antiinflammatory, antimutagenic, antibacterial and antiviral effects against the herpes simplex virus [19].

The Desmodium canadense herb contains flavonoids such as apigenin, apigenin-7-O-glucoside, luteolin, rutin, 2vicenin, vitexin, isovitexin, vitexin rhamnoside, orientin, homoorientin, quercetin, hyperoside, astragalin and kaempherol [20]. In addition, it also contains saponins and phenolic acids (chlorogenic acid, vanillic, 4- hydroxycinnamic, ferulic and caffeic). The Desmodium herb exhibits antioxidant, antibacterial, anti-inflammatory, hepatoprotective, diuretic and analgesic activity [20]. C-glycosides of flavonoids are known to exhibit antioxidant, hepatoprotective, antiinflammatory and antiviral effects [21]. The plants in this study were chosen for their medical, antibacterial and antiviral properties. Ethanol extracts of medicinal plants belonging to the families Lamiaceae (winter savory, perilla, blue giant hyssop, oregano, peppermint, lemon balm, thyme, hyssop, catnip and sage), Asteraceae (chamomile and purple coneflower), Geraniaceae (rock crane's-bill), Apiaceae (garden angelica), and Fabaceae (showy tick trefoil) were prepared. The majority of plants used for the preparation of extracts in this study belong to one of the famous medicinal aromatic plant families Lamiaceae. The medicinal plants from this family have long been used in traditional medicine worldwide.

Many investigations of plant extracts have been performed with different coronaviruses. The main targets were proteins involved in coronaviral replication, proteases and ion channel conductance [22]. Only a few investigations have been performed to test the anti-IBV activity of plant extracts. Several studies have found that the plant preparations inhibited IBV replication in vivo and vitro. Sambucus nigra, Houttuynia cordata, Alium sativum and Astragalus mongholicus inhibited IBV replication [23-26]. The ethanol extract of Sambucus nigra inhibited IBV replication and reduced virus titres prior to infection [24], as did Houttuynia cordata essential oil mixed with an aqueous solution of sodium chloride solution [25]. It is suggested that the effect of extracts of, Alium sativum, Houttuynia cordata and Sambucus nigra can be associated with direct inactivation of envelope structures of a virus, which are necessary for adsorption to or entry into host cells, or might dissolute the IBV envelope. Compounds that have a virucidal effect work like a disinfectant and do not require replication to inactivate the virus [15]. The mechanism of action of Astragalus polysaccharides has not been explained.

Medicinal plants or substances derived from them are being tested as a tool for preventing infectious diseases such as IB in many countries, but the anti-IBV viral properties of the selected plants have not so far been tested. The objective of this study was to investigate extracts of 15 selected medicinal plants for anti-IBV activity.

\section{Results \\ Cytotoxicity of plant extracts}

All the extracts were more cytotoxic $(P<0.05)$ than the ethanol control $(7.7 \mu \mathrm{l})$. A. foeniculum showed the highest cytotoxic concentration $(0.062 \mu \mathrm{g})$ and $P$. frutescens $(0.77 \mu \mathrm{g})$ showed the lowest one.

\section{Antiviral effect against IBV}

According to the results of the antiviral effect assay, eight extracts were selected for determination of the virucidal effect. The selected extracts of $S$. montana, O. vulgare, $M$. piperita, M. officinalis, T. vulgaris, $H$. officinalis, S. officinalis and $D$. canadense showed anti-IBV activity in two of the four methods. All eight extracts showed an antiviral effect prior to infection (method 1). Furthermore, seven of these showed antiviral activity during infection (method 2 ), while only the extract of $S$. montana showed anti-IBV activity after infection (method 4). P. frutescens, N. cataria, E. purpurea, Ch. nobile and A. foeniculum showed an antiviral effect only in the first method, while G. macrorrhizum and $A$. archangelica did not show an antiviral effect in any method (Table 1).

The above-mentioned eight plant extracts demonstrating anti-IBV activity were selected for further investigation. The $50 \%$ effective concentration $\left(\mathrm{EC}_{50}\right)$ was determined in cells grown for 4 days (prior to infection). The $\mathrm{EC}_{50}$ values of extracts of $S$. montana, O. vulgare, $M$. piperita, M. officinalis, T. vulgaris, $H$. officinalis, $S$. officinalis and $D$. canadense were between 0.003 and $0.076 \mu$, however $S$. officinalis appeared effective at the lowest concentration $(0.003 \mu \mathrm{g})$ (Table 2). SI of M. piperita, O. vulgare, and T. vulgaris extracts were $67.5,65.0$ and 63.1 respectively.

\section{The anti-IBV activity prior to infection in Vero cells}

The inhibitory effect of extracts against IBV prior to infection in Vero cells was measured by virus plaque and $\mathrm{TCID}_{50}$ assays. The selected plant extracts had a virucidal effect and inhibited viral replication compared to the virus control $(P<0.05)$. No virus plaques or CPE were detected 
Table 1 Antiviral effect of plant extracts

\begin{tabular}{|c|c|c|c|c|c|c|}
\hline \multirow[t]{3}{*}{ No. } & \multirow[t]{3}{*}{ Latin name (family) } & \multirow[t]{3}{*}{ Part } & \multicolumn{4}{|l|}{ Antiviral effect } \\
\hline & & & \multicolumn{3}{|c|}{ Virus pre-treatment with extract } & \multirow{2}{*}{$\begin{array}{l}\text { Cell pre- } \\
\text { treatment } \\
\text { prior to } \\
\text { infection }\end{array}$} \\
\hline & & & prior to infection & during infection & after infection & \\
\hline 1. & Satureja montana & herb & + & - & + & - \\
\hline 2. & Chamaemelum nobile & herb & + & - & - & - \\
\hline 3. & Perilla frutescens & herb & + & - & - & - \\
\hline 4. & Agastache foeniculum & herb & + & - & - & - \\
\hline 5. & Origanum vulgare & herb & + & + & - & - \\
\hline 6. & Mentha piperita & herb & + & + & - & - \\
\hline 7. & Geranium macrorrhizum & herb & - & - & - & - \\
\hline 8. & Melissa officinalis & herb & + & + & - & - \\
\hline 9. & Angelica archangelica & leaves & - & - & - & - \\
\hline 10. & & roots & - & - & - & - \\
\hline 11. & Thymus vulgaris & herb & + & + & - & - \\
\hline 12. & Hyssopus officinalis & herb & + & + & - & - \\
\hline 13. & Nepeta cataria & herb & + & - & - & - \\
\hline 14. & Echinacea purpurea & herb & + & - & - & - \\
\hline 15. & Salvia officinalis & herb & + & + & - & - \\
\hline 16. & Desmodium canadense & herb & + & + & - & - \\
\hline
\end{tabular}

after IBV treatment with extracts, whose concentrations were equivalent to 1 and $0.5 \mathrm{CC}_{50}$ (Table 3 ).

No virus plaques or CPE were detected after IBV treatment with $M$. piperita, D. canadense or T. vulgaris extracts at concentrations equivalent to between 1 and 0.25 $\mathrm{CC}_{50}$. The other five plant extracts exhibited a lower effect on inhibition of virus replication at the same concentrations. However, all extracts reduced the PFU number (PFU reduction rate was from 54.5 to $100.0 \%$ ) and TCID $_{50}$ (from 2.0 to $\left.5.0 \log _{10}\right)$ significantly $(P<0.05)$.

Table 2 Anti-IBV activity of some plant extracts in Vero cell cultures

\begin{tabular}{lllll}
\hline No. & Plant extract & $\mathrm{CC}_{50}(\mu \mathrm{g})^{\mathrm{a}}$ & $E C_{50}(\mu \mathrm{g})^{\mathrm{b}}$ & $\mathrm{SI}$ \\
\hline 1. & Satureja montana & 0.75 & 0.044 & 17.0 \\
5. & Origanum vulgare & 0.52 & 0.008 & 65.0 \\
6. & Mentha piperita & 0.27 & 0.004 & 67.5 \\
8. & Melissa officinalis & 0.59 & 0.015 & 39.3 \\
11. & Thymus vulgaris & 0.63 & 0.010 & 63.1 \\
12. & Hyssopus officinalis & 0.64 & 0.076 & 8.4 \\
15. & Salvia officinalis & 0.11 & 0.003 & 36.7 \\
16. & Desmodium canadense & 0.29 & 0.017 & 17.1 \\
\hline
\end{tabular}

${ }^{\mathrm{a}}$ The assay for determination of $\mathrm{CC}_{50}$ was performed in octuplicate for each extract

${ }^{\mathrm{b}}$ The experiments for determination of $\mathrm{EC}_{50}$ were repeated independently twice, and a mean is presented
Virus plaques and CPE were detected after IBV treatment with all extract concentrations equivalent to 0.125 $\mathrm{CC}_{50}$. All extracts decreased the PFU number (PFU reduction rate from 50.2 to $76.6 \%$ ) and TCID $_{50}$ (from 1.55 to $\left.3.17 \log _{10}\right)$ significantly $(P<0.05)$. Both PFU number and $\mathrm{TCID}_{50}$ increased significantly after the use of $M$. piperita, D. canadense, T. vulgaris and $M$. officinalis, with extract concentrations of $0.125 \mathrm{CC}_{50}$ compared to $0.25 \mathrm{CC}_{50}(P<0.05)$.

\section{Real-time RT-PCR assay}

Real-time RT-PCR detected IBV RNA after treatment with all plant extracts using concentrations equivalent to $1: 2$ $\mathrm{CC}_{50}, 1: 4 \mathrm{CC}_{50}$ and 1:8 $\mathrm{CC}_{50}$. Delta $\mathrm{Ct}$ values decreased significantly comparing the $\mathrm{Ct}$ values of $1: 2 \mathrm{CC}_{50}$ and 1:8 $\mathrm{CC}_{50}$ dilutions $(P<0.05$, Table 4$)$. The quantity of IBV RNA decreased significantly only after every dilution of M. officinalis and H. officinalis extracts (Table 4).

\section{Multidimensional data analysis}

The performed tests provided highly multidimensional data. Hierarchical clusterisation was performed using seven attributes obtained from the results of all the extracts. The seven attributes were: (1) $\mathrm{CC}_{50}$, (2) $\mathrm{EC}_{50}$, (3) SI, (4) $\mathrm{CC}_{50}$ dilution protecting $100 \%$ cells, (5) inhibition of cytopathic effect $\left(\mathrm{CIA}_{100}\right)$ method $1,(6) \mathrm{CC}_{50}$ dilution protecting $100 \%$ cells method 2 and (7) $\mathrm{CC}_{50}$ dilution protecting $100 \%$ cells method 3 . Nevertheless, complete 
Table 3 Virucidal effect and virus yield reduction

\begin{tabular}{|c|c|c|c|c|c|}
\hline No. & Plant extract & $\begin{array}{l}\text { Concentrations of plant extracts equivalent to } \\
\mathrm{CC}_{50}\end{array}$ & $\begin{array}{l}\text { PFU number }(\text { mean } \pm S D) \\
\log _{10}\end{array}$ & $\begin{array}{l}\text { PFU reduction rate, } \\
\%\end{array}$ & $\begin{array}{l}\mathrm{TCID}_{50}(\text { mean } \pm \mathrm{SD}), \\
\log _{10}\end{array}$ \\
\hline \multirow[t]{4}{*}{1.} & \multirow[t]{4}{*}{ S. montana } & 1 & 0 & 100 & 0 \\
\hline & & 0.5 & 0 & 100 & 0 \\
\hline & & 0.25 & $0.97 \pm 0.19$ & 78.0 & $0.75 \pm 0.64^{a}$ \\
\hline & & 0.125 & $1.03 \pm 0.11$ & 76.6 & $1.83 \pm 0.31^{c x}$ \\
\hline \multirow[t]{4}{*}{5.} & \multirow[t]{4}{*}{ O. vulgare } & 1 & 0 & 100 & 0 \\
\hline & & 0.5 & 0 & 100 & 0 \\
\hline & & 0.25 & $1.08 \pm 0.00$ & 75.4 & $1.00 \pm 0.94^{a}$ \\
\hline & & 0.125 & $1.40 \pm 0.32$ & 68.2 & $2.48 \pm 0.23^{d x}$ \\
\hline \multirow[t]{4}{*}{6.} & \multirow[t]{4}{*}{ M. piperita } & 1 & 0 & 100 & 0 \\
\hline & & 0.5 & 0 & 100 & 0 \\
\hline & & 0.25 & 0 & 100 & $0^{\mathrm{a}}$ \\
\hline & & 0.125 & $1.48 \pm 0.05^{x}$ & 66.4 & $2.63 \pm 0.13^{d x}$ \\
\hline \multirow[t]{4}{*}{8.} & \multirow[t]{4}{*}{ M. officinalis } & 1 & 0 & 100 & 0 \\
\hline & & 0.5 & 0 & 100 & 0 \\
\hline & & 0.25 & $0.15 \pm 0.21$ & 96.6 & $0.56 \pm 0.44^{a}$ \\
\hline & & 0.125 & $1.72 \pm 0.01^{x}$ & 60.9 & $3.38 \pm 0.21$ ex \\
\hline \multirow[t]{4}{*}{11.} & \multirow[t]{4}{*}{ T. vulgaris } & 1 & 0 & 100 & 0 \\
\hline & & 0.5 & 0 & 100 & 0 \\
\hline & & 0.25 & 0 & 100 & 0 \\
\hline & & 0.125 & $1.70 \pm 0.01^{x}$ & 61.3 & $3.25 \pm 0.22^{e x}$ \\
\hline \multirow[t]{4}{*}{12.} & \multirow[t]{4}{*}{ H. officinalis } & 1 & 0 & 100 & 0 \\
\hline & & 0.5 & 0 & 100 & 0 \\
\hline & & 0.25 & $1.33 \pm 0.01$ & 69.8 & $3.00 \pm 0.29^{b}$ \\
\hline & & 0.125 & $2.00 \pm 0.03^{x}$ & 54.5 & $3.35 \pm 0.29^{e}$ \\
\hline \multirow[t]{4}{*}{15.} & \multirow[t]{4}{*}{ S. officinalis } & 1 & 0 & 100 & 0 \\
\hline & & 0.5 & 0 & 100 & 0 \\
\hline & & 0.25 & $2.00 \pm 0.00$ & 54.5 & $3.25 \pm 0.25^{b}$ \\
\hline & & 0.125 & $2.19 \pm 0.03^{x}$ & 50.2 & $3.45 \pm 0.21^{\mathrm{e}}$ \\
\hline \multirow[t]{5}{*}{16.} & \multirow{4}{*}{$\begin{array}{l}\text { D. } \\
\text { canadense }\end{array}$} & 1 & 0 & 100 & 0 \\
\hline & & 0.5 & 0 & 100 & 0 \\
\hline & & 0.25 & 0 & 100 & $0^{\mathrm{a}}$ \\
\hline & & 0.125 & $1.70 \pm 0.01^{\times}$ & 61.3 & $2.75 \pm 0.16^{d}$ \\
\hline & IBV (control) & - & $4.40 \pm 0.09$ & - & $5.00 \pm 0.19$ \\
\hline
\end{tabular}

${ }^{x}$ means that the $\mathrm{PHU}$ number and $\mathrm{TCID}_{50}$ difference within the group (plant extract concentrations 0.25 and $\left.0.125 \mathrm{CC}_{50}\right)$ was statistically significant $(P<0.05)$; if groups do not share a common letter ${ }^{\text {a and } b}$ it means that the $\mathrm{TCID}_{50}$ (plant extract concentration $0.25 \mathrm{CC}_{50}$ ) difference between the groups was statistically significant $(P<0.05)$; if groups do not share a common letter ${ }^{c, d \text { and } e}$ it means that the $\mathrm{TCID}_{50}$ (plant extract concentration $\left.0.125 C_{50}\right)$ difference between the groups was statistically significant $(P<0.05)$

inhibition of the cytopathic effect $\left(\mathrm{CIA}_{100}\right)$ method 4 was not used for calculations due to the fact that this experiment indicated inactivity for all tested extracts. As can be seen in Fig. 1a, three sub-clusters can be distinguished: (1) anti-IBV inactive (A. foeniculum, C. nobile, G. macrorrhizum, A. archangelica roots and aerial part), (2) anti-IBV active (D. canadense, $M$. piperita, M. officinalis, O. vulgare, S. officinalis, T. vulgaris) and (3) hybrid sub-cluster (E. purpurea, S. montana, N. cataria, P. frutescens, H. officinalis). H. officinalis and S. montana were clustered belonging to the hybrid sub-cluster containing anti-IBV inactive and active plant extracts. This observation can be explained by the fact that $H$. officinalis and $S$. montana exhibited the lowest cytotoxicity and the lowest anti-IBV effect among the anti-IBV active plant extracts. 
Table 4 Delta Ct values - comparison with the virus control by real-time RT-PCR assay

\begin{tabular}{lllll}
\hline No. & Plant extract & \multicolumn{3}{l}{ Delta Ct values ${ }^{\times}$} \\
\cline { 2 - 4 } & & $1: 2 \mathrm{CC}_{50}$ & $1: 4 \mathrm{CC}_{50}$ & $1: 8 \mathrm{CC}_{50}$ \\
\hline 1. & Satureja montana & $14.06 \pm 2.50^{1}$ & $3.82 \pm 0.95^{2}$ & $3.32 \pm 0.65^{2}$ \\
5. & Origanum vulgare & $13.28 \pm 2.73^{1}$ & $7.40 \pm 1.01^{2}$ & $6.36 \pm 1.01^{2}$ \\
6. & Mentha piperita & $18.32 \pm 2.77^{1}$ & $8.24 \pm 1.06^{2}$ & $7.70 \pm 1.82^{2}$ \\
8. & Melissa officinalis & $12.49 \pm 2.33^{1}$ & $8.41 \pm 2.22^{2}$ & $2.71 \pm 0.94^{3}$ \\
11. & Thymus vulgaris & $12.65 \pm 1.00^{1}$ & $11.70 \pm 1.17^{1}$ & $2.66 \pm 0.77^{2}$ \\
12. & Hyssopus officinalis & $10.02 \pm 2.50^{1}$ & $5.33 \pm 2.10^{2}$ & $2.03 \pm 1.10^{3}$ \\
15. & Salvia officinalis & $8.25 \pm 1.86^{1}$ & $6.65 \pm 1.19^{1}$ & $1.95 \pm 1.19^{2}$ \\
16. & Desmodium canadense & $16.41 \pm 2.44^{1}$ & $10.58 \pm 2.82^{2}$ & $6.21 \pm 0.64^{2}$ \\
\hline
\end{tabular}

${ }^{\mathrm{X}} \mathrm{Ct}$ of IBV was $18.50 \pm 1.66 ;{ }^{1,2}$ and ${ }^{3}$ means that the difference within the group was statistically significant $(P<0.05)$

The comparison of different anti-IBV active plant extracts was performed using a multidimensional scaling technique. The obtained results of anti-IBV extracts indicated highly multidimensional data (12 attributes), which cannot be visualised without additional mathematical means. The multidimensional scaling technique allows the projection of all dimensions to two dimensions, which are easily represented in the plot. In this study, 12 dimensions - (1) $\mathrm{CC}_{50}$, (2) $\mathrm{EC}_{50}$, (3) SI, (4) PFU number at dilution of 0.25 , (5) PFU number at dilution of 0.125 , (6) PFU reduction rate at dilution of 0.25 , (7) PFU reduction rate at dilution of $0.125,(8) \mathrm{TCID}_{50}$ at dilution of 0.25 , (9) $\mathrm{TCID}_{50}$ at dilution of 0.125 , (10) Delta $\mathrm{Ct}$ values at $1: 2 \mathrm{CC}_{50},(11)$ Delta $C t$ values at 1:4 $\mathrm{CC}_{50}$ and (12) Delta $\mathrm{Ct}$ values at 1:8 $\mathrm{CC}_{50}$ - were projected to two dimensionless projections (Coordinate 1 and Coordinate 2). Other attributes were not used for multidimensional scaling since they indicated similar numeric values. In the plot (Fig. 1b) four extreme points were identified: (i) S. montana (lowest cytotoxicity), (ii) H. officinalis (lowest anti-IBV activity) (iii) S. officinalis (highest cytotoxicity and anti-IBV activity) and (iv) $M$. piperita (highest SI). In the plot (Fig. 1b) there is a cluster of moderately active plant extracts: $O$. vulgare, $M$. officinalis, T. vulgaris and D. canadense. It should be noted that $M$. piperita extract is more similar to the moderately active cluster than other extreme points (S. montana, H. officinalis, S. officinalis). Interestingly, D. canadense is more similar to a moderately active cluster with dominating plants of family Lamiaceae, whereas D. canadense belongs to the family Fabaceae.

\section{Discussion}

A wide range of traditional medicinal plants and herbs have been reported to show antiviral activities against various viruses. In this study, the anti-IBV activities were analysed of ethanol extracts from 16 medicinal plants that belong to 15 different species. In screening, the IBV Beaudette strain was used because it is adapted to the Vero cell culture system. A Vero cell line was used as it is one of the most common and well-established mammalian cell lines involved in assessing the effects of chemicals, toxins and other substances at the molecular level [27]. The cell line is also known to be susceptible to many viruses, including IBV, and displays CPE upon infection.

First, the cytotoxicity of plant extracts was evaluated before the possible mechanisms of virus inhibition were determined. Eight out of 16 extracts $-D$. canadense, $M$. piperita, M. officinalis, O. vulgaris, T. vulgaris, $H$. officinalis, S. officinalis, and S. montana - were chosen based on the results of the antiviral effect assay. The first seven extracts mentioned above possessed significant anti-IBV activities prior to/during infection, and only S. montana had an antiviral effect prior to and post-infection. All extracts, except $D$. canadense, belong to the Lamiaceae family, members of which have been reported in many studies as showing antiviral activity [28-30]. So far, none

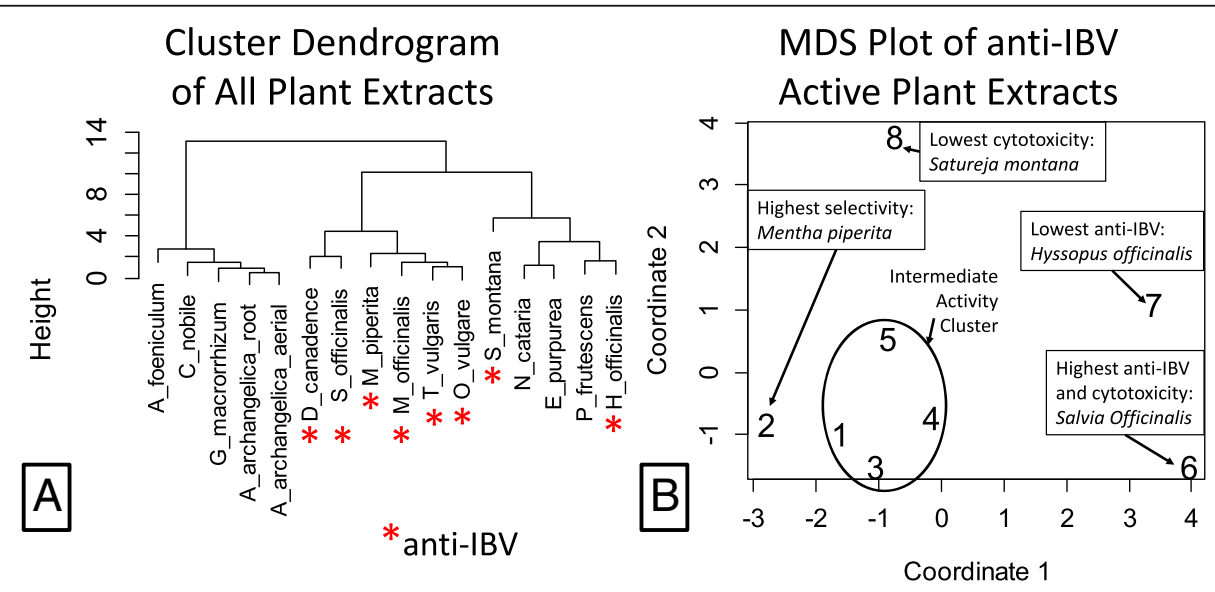

Fig. 1 Visual representation of the experimental data. a Cluster dendrogram of all plant extracts. b Multidimensional Scaling plot of anti-IBV active plant extracts. Plant extracts: 1 - D. canadense, 2 - M. piperita, 3 - T. vulgaris, $4-$ M. officinalis, 5 - O. vulgare, 6 - S. officinalis, $7-$ H. officinalis, 8 S. montana 
of these plants has been studied for antiviral activity against IBV. However, several preparations of botanicals inhibit viral replication in vitro and in vivo. Moreover, the results show that ethanol extract of Sambucus nigra inhibits viral replication and reduces virus titres prior to infection [24], as does Houttuynia cordata essential oil mixed with an aqueous solution of sodium chloride solution [25]. These results suggest that the effect of extracts can be associated with the direct inactivation of the envelope structures of a virus, which are necessary for adsorption to or entry into host cells, or might dissolute the IBV envelope. Thus, resistance to virucidal compounds due to mutations generated in the viral genome during replication is not likely [31].

Subsequently, the anti-IBV activities were examined of those eight plant extracts that showed the strongest antiviral activity prior to infection, using plaque reduction assay to determine the virucidal effect. Furthermore, $M$. piperita, D. canadense and T. vulgaris extracts exhibited the strongest viral replication inhibition, and completely stopped IBV production at 1 to $0.25 \log _{10} \mathrm{CC}_{50}$ concentration. Comparable results were also obtained by $\mathrm{TCID}_{50}$ assay. The extract of $M$. officinalis showed a slightly lower virucidal effect and at $0.25 \log _{10}$ the $\mathrm{CC}_{50}$ concentration PFU number $\left(\log _{10}\right)$ was $0.15 \pm 0.21$. It has been reported that the aqueous extract of $M$. piperita shows anti-HIV-1 activity in MT-4 cells and inhibitory activity against HIV-reverse transcriptase [32]. Moreover, hydroalcoholic and aqueous extracts of $M$. piperita and T. vulgaris have been shown to exert significant anti-HSV-1 and anti-HSV-2 activities in vitro. M. piperita essential oil has been found to be significantly effective against both HSV -1 [28] and HSV-2 when the viruses are treated with peppermint oil prior to adsorption, but not after penetration into the host cell [31]. An increase in virion density prior to its attachment to the host cells is the most likely mechanism of action of the antiviral activity of the aqueous extract of M. piperita [33].

The results of real-time PCR showed that this method can be successfully used to evaluate and compare the antiviral effect of plant extracts. However, it is important to note that simple or RT-PCR detects viral RNA of both an inactivated virus and an intact one. Therefore, it is not possible to assess the percentages of the nucleic acid of live and killed viruses in the sample. It is likely that the influence of the higher amounts of inactivated IBV on Delta Ct values could be significant, in some cases. It is more likely when the higher effective concentrations of plant extracts were used. RT-PCR showed that the IBV RNA quantity was statistically higher in all cases in a comparison after IBV treatment with extracts concentrations of $1: 2$ and 1:8 $C_{50}$. The RT-PCR confirmed that extracts of $M$. piperita and D. canadense had the highest effect on the synthesis of viral RNA.

These results were unable to reveal the most anti-IBV effective plant extract. Therefore, multidimensional data analysis was carried out using hierarchical clusterisation. It identified an anti-IBV active cluster with $M$. piperita, T. vulgaris, D. canadense, M. officinalis, S. officinalis and $O$. vulgare. Multidimensional scaling technique identified four extreme points: (i) S. montana, which provided the lowest cytotoxicity, (ii) H. officinalis, which provided the lowest anti-IBV activity, (iii) S. officinalis, which provided the highest cytotoxicity and anti-IBV activity, and (iv) M. piperita, which provided the highest SI.

In this study, the majority of plant extracts were found to have some antiviral activity and could inhibit IBV prior to and during infection. The ethanolic extracts had a mixture of compounds/fractions and it is possible that the antiviral activity of plants is decided by one or several compounds or combinations thereof [34]. Future studies are needed to detect the compounds or fractions responsible for anti-IBV activity and to investigate the mechanism of their action.

\section{Conclusions}

Many extracts of plants acted virucidally against IBV prior to and during infection, but those of M. piperita, $T$. vulgaris and $D$. canadense were the most effective.

\section{Materials and methods}

\section{Plants and extracts}

All the plants were grown in the botanical garden of Vytautas Magnus University (Lithuania). Sixteen ethanol extracts were prepared from medicinal plants. The content of biologically active compounds is dependent on the edaphoclimatic conditions of the plant's cultivation, the vegetation phase, the phenotype and the method of preparation of the raw material. Previous studies comparing the dried raw and fresh material of medicinal plants and different sample preparation methods have shown that drying and other conditions affect the qualitative and quantitative composition of the raw material $[35,36]$. In many cases, drying is used as a standardised preparation of raw material of medicinal plants since it reduces water content and the risk of microbiological spoilage of raw material. In the present study, drying was used to collect all the samples of different plants during the intensive blooming vegetation phase for the simultaneous determination of biological activities, in consideration of the fact that different medicinal plants differ in dynamics of the accumulation of biologically active compounds, vegetation, and therefore in the harvesting of raw material [37]. The potentially antiviral plants were selected for extraction depending on the accumulated compounds in herbs, leaves and roots. 


\section{Preparation of plant extracts}

The solvent ethanol was diluted with sterile bidistilled water to $40 \%$ (vol.) concentration. Dried plant material from each plant $(500 \mu \mathrm{g})$ was extracted with $10 \mathrm{ml}$ solvent. The extraction was performed in an orbital shaker for $24 \mathrm{~h}$ at room temperature $\left(20^{\circ} \mathrm{C}\right)$. Each extract was filtrated using a paper filter and then polyvinyl difluoride membrane filter with $0.22-\mu \mathrm{m}$ pore size. The concentration of the extracts was $50 \mathrm{mg} / \mathrm{ml}$, with reference to the starting material. All the prepared plant extracts were stored in a refrigerator at $4{ }^{\circ} \mathrm{C}$.

\section{Cell line}

Vero cells (ATCC CCL-81) were provided by Dr. I. Jacevičienè from the Department of Virus Research at the National Food and Veterinary Risk Assessment Institute in Lithuania. The cells were cultivated in Dulbecco's modified Eagle's medium (DMEM) supplemented with $10 \%$ foetal bovine serum (FBS) at $37^{\circ} \mathrm{C}$ in $5 \% \mathrm{CO}_{2}$ incubator. Nystatin (100 units/ml) and gentamycin $(50 \mu \mathrm{g} /$ $\mathrm{ml}$ ) were used to prevent microbial contamination.

\section{Virus}

The Vero-adapted Beaudette IBV strain was used. The virus was provided by Dr. M. H. Verheije of Utrecht University in The Netherlands. The virus stocks were prepared and stored at $-80^{\circ} \mathrm{C}$ in aliquots.

\section{Cytotoxicity assay}

The cytotoxic concentration $\left(\mathrm{CC}_{50}\right)$ was determined for each extract on Vero cells using MTT assay [38]. First, cells were seeded at a concentration of $1 \times 10^{4}$ cells/well in a 96-well plate and grown at $37^{\circ} \mathrm{C}$ for $24 \mathrm{~h}$. Each extract was tested in octuplicate once. After $72 \mathrm{~h}$ MTT reagent (10 $\mu \mathrm{l}, 5 \mathrm{mg} / \mathrm{ml}$, Sigma-Aldrich) was added and incubated for $4 \mathrm{~h}$ at $37^{\circ} \mathrm{C}$. Then $100 \mu \mathrm{l}$ dimethyl sulphoxide (DMSO) (Carl Roth, Germany) was added to each well and the plates were placed on the shaker for $5 \mathrm{~min}$. The absorbance of each well was measured at $620 \mathrm{~nm}$ in a microplate reader (Multiskan ${ }^{\mathrm{Tm}}$ FC Microplate Photometer) and the percentage of cell survival was calculated. Finally, doseresponse curves were plotted to enable the calculation of $\mathrm{CC}_{50}$ that causes lysis and death in $50 \%$ of cells.

\section{Screening extracts for antiviral activity}

For determination of antiviral properties, one-day-old Vero cells (seeded $1 \times 10^{4}$ cells/well) in a 96-well plate were used. The virus was used at a multiplicity of infection (MOI) of 0.05 . Each extract was serially diluted twofold to 1:128 in DMEM and assessed for the ability to inhibit IBV replication using four mechanisms. Every sample of extract was tested twice in quadruplicate. In addition, controls of cells, the virus and extracts were included. An inverted microscope (Leica, Germany) was used to observe cells after all procedures.

In the first method, the virus was treated with the diluted extract for $1 \mathrm{~h}$ in a separate 96-well plate and then poured onto the cells. The mixtures were discarded after incubation for $1 \mathrm{~h}$ at $37 \mathrm{C}$ in $5 \% \mathrm{CO}_{2}$ and then the cells were washed twice with PBS. After washing, DMEM containing $2 \%$ of FBS was added. Observation by microscopy for inhibition of cytopathic effect (CPE) was performed after incubation for $72 \mathrm{~h}$ at $37^{\circ} \mathrm{C}$ in $5 \% \mathrm{CO}_{2}$.

In the second method, the mixtures of virus and the diluted extract were poured onto the cells immediately. The mixtures were discarded after incubation for $1 \mathrm{~h}$ at $37^{\circ} \mathrm{C}$ in $5 \% \mathrm{CO}_{2}$ and then the cells were washed twice with PBS. After washing, DMEM containing $2 \%$ of FBS was added. Observation by microscopy for inhibition of $\mathrm{CPE}$ was performed after incubation for $72 \mathrm{~h}$ at $37^{\circ} \mathrm{C}$ in $5 \% \mathrm{CO}_{2}$.

In the third method, the cells were inoculated with the virus and then treated with extract. First the cells were inoculated with the virus and incubated for $1 \mathrm{~h}$ at $37^{\circ} \mathrm{C}$ in $5 \% \mathrm{CO}_{2}$. Then the unadsorbed virus was discarded and the cells were washed twice with PBS. After washing, the cells were treated with the diluted extracts for 1 $\mathrm{h}$ at $37^{\circ} \mathrm{C}$ in $5 \% \mathrm{CO}_{2}$. After washing the cells twice with PBS, DMEM containing 2\% of FBS was added. Observation by microscopy for inhibition of CPE was performed after incubation for $72 \mathrm{~h}$ at $37^{\circ} \mathrm{C}$ in $5 \% \mathrm{CO}_{2}$.

In the fourth method, the cells were treated with extract prior to inoculation. First the cells were treated with the diluted extracts for $1 \mathrm{~h}$ at $37^{\circ} \mathrm{C}$ in $5 \% \mathrm{CO}_{2}$. Then the cells were washed twice with PBS and inoculated with the virus. After incubation for $1 \mathrm{~h}$ at $37^{\circ} \mathrm{C}$ in $5 \% \mathrm{CO}_{2}$ the cells were washed twice with $\mathrm{PBS}$, and DMEM containing $2 \%$ of FBS was added. Observation by microscopy for inhibition of CPE was performed after incubation for $72 \mathrm{~h}$ at $37^{\circ} \mathrm{C}$ in $5 \% \mathrm{CO}_{2}$.

The most promising plant extracts were selected for determination of $\mathrm{EC}_{50}$ and selectivity index (SI) based on the results of the antiviral effect assay.

\section{Determination of $\mathrm{EC}_{50}$ and $\mathrm{SI}$}

Eight out of 16 plant extracts were chosen for the determination of $\mathrm{EC}_{50}$ and SI using the first method. Extracts were titrated from 1 to $1: 128 \mathrm{CC}_{50}$ and used for virus treatment. After $72 \mathrm{~h}$ the MTT assay was performed as outlined above. The $50 \%$ effective concentrations $\left(E_{50}\right)$ were calculated from the plot of percentages of cell viability against extract concentrations.

\section{Plaque reduction assay}

Concentrations of extracts from $1 \mathrm{CC}_{50}$ to $0.125 \mathrm{CC}_{50}$ and 25,000 plaque-forming units (PFU) of IBV were mixed and incubated at room temperature for $1 \mathrm{~h}$. 
Plant extracts were diluted with DMEM to prepare four concentrations equivalent to $1 \mathrm{CC}_{50}, 0.5 \mathrm{CC}_{50}, 0.25$ $\mathrm{CC}_{50}$, and $0.125 \mathrm{CC}_{50}$, as calculated by cytotoxicity assay. These dilutions were then mixed with 25,000 plaque-forming units (PFU) of IBV and incubated at room temperature for $1 \mathrm{~h}$. After incubation, a confluent monolayer of Vero cells in 6-well plates was inoculated with $1 \mathrm{ml}$ of virus (MOI 0.05) and plant extract mixtures for $1 \mathrm{~h}$ at $37^{\circ} \mathrm{C}$ in $5 \% \mathrm{CO}_{2}$ and then discarded. The agarose $0.4 \%$ in maintenance medium was added to cells, and the plates were stored at room temperature for 15 min and incubated at $37^{\circ} \mathrm{C}$ and $5 \% \mathrm{CO}_{2}$. After $72 \mathrm{~h}$ the plates were microscopically examined for detection of CPE and then $0.2 \mathrm{ml} \mathrm{MTT}(5 \mathrm{mg} / \mathrm{ml}$ ) was used for staining. Plaques were counted after incubation at $37^{\circ} \mathrm{C}$ in $5 \% \mathrm{CO}_{2}$ for $4 \mathrm{~h}$. The number of plaques was expressed as $\log _{10}$ and the reduction rate was calculated as follows:

PFU number of virus control-PFU number after the treatment with plant extract PFU number of virus control

\section{Virus yield reduction}

A virus yield reduction was evaluated by means of virus titration and real-time reverse transcriptase polymerase chain reaction (RT-PCR). The cells were inoculated as outlined above in the plaque reduction assay section. Plant extracts were diluted with DMEM to prepare four concentrations equivalent to $1 \mathrm{CC}_{50}, 0.5 \mathrm{CC}_{50}, 0.25$ $\mathrm{CC}_{50}$, and $0.125 \mathrm{CC}_{50}$ as calculated by cytotoxicity assay. These dilutions were then mixed with 25,000 plaqueforming units (PFU) of IBV and incubated at room temperature for $1 \mathrm{~h}$. After incubation a confluent monolayer of Vero cells in 6-well plates was inoculated with 1 $\mathrm{ml}$ of virus (MOI 0.05) and plant extract mixtures for $1 \mathrm{~h}$ at $37^{\circ} \mathrm{C}$ in $5 \% \mathrm{CO}_{2}$, and then discarded. After inoculation DMEM containing $2 \%$ of FBS was added and the cells were incubated for $24 \mathrm{~h}$. CPE of the virus was evaluated using light microscopy. After that, the plates were frozen and thawed three times and the aliquots of the virus were prepared by centrifugation for $15 \mathrm{~min}$ at 2000 RPM. The prepared mixtures were used for quantification of both treated and untreated virus and viral nucleic acids by means of $\mathrm{TCID}_{50}$ assay and quantitative realtime RT-PCR respectively.

\section{$\mathrm{TCID}_{50}$ assay}

Determination of $\mathrm{TCID}_{50}$ of the control virus and the treated one was performed in 96-well plates. CPE was evaluated after 7 days. Virus titres were calculated using the Kärber method (Kärber, 1931).

\section{Real-time RT-PCR assay}

Ribonucleic acid (RNA) used in the real-time RT-PCR was extracted by means of TRIzol Reagent (Thermo
Fisher Scientific, USA) according to the manufacturer's instructions. Real-time RT-PCR was performed as described by Meir [39]. Briefly, a conserved region of 336 base pairs located at nucleotide position 741-1077 of the H120 strain $\mathrm{N}$ gene sequence (GenBank accession no. AM260960) was used to design primers and probe for the real-time RT-PCR assay. A downstream primer IBV-f (5-ATGCTCAACCTTGTCCCTAGCA-3) located at nucleotide position 811-832, an upstream primer IBV-r (5-TCAA-ACTGCGGATCATCACGT-3) located at nucleotide position 921-941, and a TaqMan ${ }^{\circledR}$ probe IBV-TM (FAM-TTGGAAGTAGAGTGACGCCCAAACTTCA-BHQ1) located at nucleotide position 848-875 were used to amplify a 130-bp fragment. Both the primers and the probe were synthesised by Applied Biosystems, UK. The $25 \mu \mathrm{l}$ real-time RT-PCR reaction contained $12.5 \mu \mathrm{l} 2 \times$ RT-PCR buffer mix (AgPath ${ }^{\text {TM }}$ OneStep RT-PCR kit, Applied Biosystems), $1 \mu \mathrm{l} 25 \times$ RT-PCR enzyme mix (Applied Biosystems), primers to a final concentration of $400 \mathrm{nM}$, probe to a final concentration of $120 \mathrm{nM}, 2 \mu \mathrm{l}$ RNA template, and nuclease-free water. The reaction was carried out in StepOne ${ }^{\mathrm{TM}}$ Plus real-time PCR system (Applied Biosystems) at $45^{\circ} \mathrm{C}$ for $10 \mathrm{~min}$, $95^{\circ} \mathrm{C}$ for $10 \mathrm{~min}$, and 40 cycles of $95^{\circ} \mathrm{C}$ for $15 \mathrm{~s}$ and $60^{\circ}$ $\mathrm{C}$ for $45 \mathrm{~s}$. Amplification plots were recorded and analysed, and the threshold cycle $(\mathrm{Ct})$ was determined with the Mastercycler RealPlex ${ }^{2}$ (Eppendorf).

The real-time RT-PCR was repeated four times, and then delta $\mathrm{Ct}$ values were calculated by subtracting the $\mathrm{Ct}$ values of virus control from $\mathrm{Ct}$ values of virus samples treated with plant extracts. Means and standard deviations of delta $\mathrm{Ct}$ values were then calculated to evaluate the effect of plant extracts on viral replication.

\section{Statistical and data analysis}

The differences between the methods and extracts were evaluated by Fisher's criteria and the Student's t-test. The data were regarded as significant when $P<0.05$. Hierarchical clusterisation and multidimensional scaling (MDS) were performed using the software R-Studio. For hierarchical clusterisation, the Euclidean method was used. For MDS, the Euclidean method was used projecting all dimensions to two dimensions.

\footnotetext{
Abbreviations

$\mathrm{CC}_{50}$ : 50\% cytotoxic concentration; $\mathrm{ClA}_{100}$ : Complete inhibition of cytopathic effect; CPE: Cytopathic effect; Ct: Threshold cycle; DMEM: Dulbecco's modified Eagle's medium; DMSO: Dimethyl sulphoxide; EC 50: 50\% effective concentrations; FBS: Foetal bovine serum; IB: Avian infectious bronchitis; IBV: Avian infectious bronchitis virus; MDS: Multidimensional scaling; MOI: Multiplicity of infection; PBS: Phosphate-buffered saline; PCR: Polymerase chain reaction; PFU: Plaque-forming unit; RNA: Ribonucleic acid; RPM: Revolutions per minute; RT-PCR: Reverse transcription polymerase chain reaction; SI: Selectivity index; $\mathrm{TCID}_{50}$ : $50 \%$ tissue culture infectious dose
} 


\section{Authors' contributions}

AM and AS proposed the experiment. OR, RM and LK chose medicinal plants. OR prepared the plants for extraction, TD and NT prepared the extracts of plants, RL and AK tested the extracts of plants. RL, AK, AS, and TD analysed the information. RL, AK, AS, AM, and TD reviewed the manuscript. All the authors read and approved the final manuscript.

\section{Funding}

The research was granted by Research Council of Lithuania, project No. MIP065/2015. Neither the design of the study, nor the collection, analysis, and interpretation of data and writing the manuscript was influenced by Research Council of Lithuania.

\section{Availability of data and materials}

The datasets supporting the results of this document are contained within the article. Any additional data may be requested to the corresponding author.

\section{Ethics approval and consent to participate}

'Not Applicable'.

\section{Competing interests}

The authors declare that they have no competing interests.

\begin{abstract}
Author details
${ }^{1}$ Institute of Microbiology and Virology, Veterinary Faculty, Lithuanian University of Health Sciences, Kaunas, Lithuania. ${ }^{2}$ Department of Veterinary Pathobiology, Veterinary Faculty, Lithuanian University of Health Sciences, Kaunas, Lithuania. ${ }^{3}$ Instrumental Analysis Open Access Centre, Vytautas Magnus University, Kaunas, Lithuania. ${ }^{4}$ Sector of Medicinal Plants, Kaunas Botanical Garden of Vytautas Magnus University, Kaunas, Lithuania. ${ }^{5}$ Faculty of Pharmacy, Lithuanian University of Health Sciences, Kaunas, Lithuania.
\end{abstract}

Received: 15 March 2018 Accepted: 20 May 2019

Published online: 29 May 2019

\section{References}

1. Cook JKA, Jackwood M, Jones RC. The long view: 40 years of infectious bronchitis research. Avian Pathol. 2012;41:239-50.

2. Cavanagh D. Coronavirus avian infectious bronchitis virus. Vet Res. 2007; 38:281-97.

3. Cavanagh D. Coronaviruses in poultry and other birds. Avian Pathol. 2005; 34:439-48.

4. Lee HJ, Youn HN, Kwon JS, Lee YJ, Kim JH, Lee JB, Park SY, Choi IS, Song CS. Characterization of a novel live attenuated infectious bronchitis virus vaccine candidate derived from a Korean nephropathogenic strain. Vaccine. 2010;28:2887-94.

5. Mahmood ZH, Sleman RR, Uthman AU. Isolation and molecular characterization of Sul/01/09 avian infectious bronchitis virus, indicates the emergence of a new genotype in the Middle East. Vet Microbiol. 2011;150:21-7.

6. Worthington KJ, Currie RJW, Jones RC. A reverse transcriptase polymerase chain reaction survey of infectious bronchitis virus genotypes in Western Europe from 2002 to 2006. Avian Pathol. 2008; 37:247-57.

7. Xu C, Zhao J, Hu X, Zhang G. Isolation and identification of four infectious bronchitis virus strains in China and analyses of their S1 glycoprotein gene. Vet Microbiol. 2007;122:61-71.

8. Liu HJ, Lee LH, Shih WL, Lin MY, Liao MH. Detection of infectious bronchitis virus by multiplex polymerase chain reaction and sequence analysis. J Virol Methods. 2003;109:31-7.

9. Chandra S, Rawat DS. Medicinal plants of the family Caryophyllaceae: a review of ethno-medicinal uses and pharmacological properties. Integr Med Res. 2015;4:123-31.

10. Shayganni E, Bahmani M, Asgary S, Rafieian-Kopaei M. Inflammaging and cardiovascular disease: management by medicinal plants. Phytomedicine. 2016;23:1119-26.

11. Kama-Kama F, Midiwo J, Nganga J, Maina N, Schiek E, Omosa LK, Osanjo G, Naessens J. Selected ethno-medicinal plants from Kenya with in vitro activity against major African livestock pathogens belonging to the "Mycoplasma mycoides cluster". J Ethnopharmacol. 2016;192:524-34.
12. Gupta D, Dubey J, Kumar M. Phytochemical analysis and antimicrobial activity of some medicinal plants against selected common human pathogenic microorganisms. Asian Pacific J Trop Dis. 2016;6:15-20.

13. Gandhi GR, Barreto PG, Lima BD, Quintans JS, Araújo AA, Narain N, Quintans-Júnior $L$, Gurgel RQ. Medicinal plants and natural molecules with in vitro and in vivo activity against rotavirus: a systematic review. Phytomedicine. 2016;23:1830-42.

14. Visintini Jaime MF, Redko F, Muschietti LV, Campos RH, Martino VS, Cavallaro LV. In vitro antiviral activity of plant extracts from Asteraceae medicinal plants. Virol J. 2013;10:245.

15. Schuhmacher A, Reichling J, Schnitzler P. Virucidal effect of peppermint oil on the enveloped viruses herpes simplex virus type 1 and type 2 in vitro. Phytomedicine. 2003;10:504-10.

16. Kaškoniene $V$, Stankevičius M, Drevinskas T, Akuneca I, Kaškonas $P$, Bimbiraitè-Survilienè K, Maruška A, Ragažinskienė O, Kornyšova O, Briedis V, Ugenskiene R. Evaluation of phytochemical composition of fresh and dried raw material of introduced Chamerion angustifolium L. using chromatographic, spectrophotometric and chemometric techniques. Phytochemistry. 2015;115:184-93.

17. Alkan T, Nitta A, Mizoguguchi H, Itob A, Nabeshima T. A natural svacenger of peroxynitrites, rosmarinic acid, protects against impairment of memory incluced by Aß25-35. Behav Brain Sci. 2007;180(2):139-45.

18. Dasmalchi K, Ollilainen V, Lackmanc P, Ollilainen V, Gennäs GB, Dorman HJD, Järvinen PP. Acetylcholinesterase inhibitory guided fractionation of Melissa officinalis L. Bioorgan Med Chem. 2009;17:867-71.

19. Razborsek MI, Voncina DB, Dolecek V, Voncina E. Determination of major phenolic acids, phenolic Diterpenes and Triterpenes in rosemary (Rosmarinus officinalis L.) by gas chromatography and mass spectrometry. Acta Chim Slov. 2007;54:60-7.

20. Inouye K, Takano H, Shiga A, Fujita Y, Makino H, Yanagisawa R, Kato Y, Yoshikawa T. Effects of volatile constituents of rosemary extract on lung inflammation induced by diesel exhaust particles Ken-ichiro. Basic Clin Pharmacol Toxicol. 2006;99:52-7.

21. Puodžiūnienè $G$, Janulis V, Ivanauskas L, Barsteigienè Z, Ribokaite $V$, Ragažinskienè O. Quantitative HPLC estimation of flavonoids in showy tick trefoil herbs. Pharm Chem J. 2009:43(5):263-6.

22. Jackwood MW, Rosenbloom R, Petteruti M, Hilt DA, McCall AW, Williams SM Avian coronavirus infectious bronchitis virus susceptibility to botanical oleoresins and essential oils in vitro and in vivo. Virus Res. 2010;148:86-94.

23. Mohajer Shojai T, Ghalyanchi Langeroudi A, Karimi V, Barin A, Sadri N. The effect of Allium sativum (garlic) extract on infectious bronchitis virus in specific pathogen free embryonic egg. Avicenna J Phytomed. 2016;6:458-67.

24. Chen C, Zuckerman DM, Brantley S, Sharpe M, Childress K, Hoiczyk E, Pendleton AR. Sambucus nigra extracts inhibit infectious bronchitis virus at an early point during replication. BMC Vet Res. 2014;10:24.

25. Yin J, Li G, Li J, Yang Q, Ren X. In vitro and in vivo effects of Houttuynia cordata on infectious bronchitis virus. Avian Pathol. 2011;40(5):491-8.

26. Zhang P, Liu X, Wang W, Liu H, Liu X, Li X, Wu X. Astragalus polysaccharides inhibit avian infectious bronchitis virus infection by regulating viral replication. Microb Pathog. 2017;114:124-8.

27. Ammerman NC, Beier-Sexton M, Azad AF. Growth and maintenance of Vero cell lines. Curr Protoc Microbiol. 2008;Appendix 4:Appendix 4E.

28. Kawahata T, Otake T, Mori H, Kojima Y, Oishi I, Oka S, Fukumori Y, Sano K. A novel substance purified from Perilla frutescens Britton inhibits an early stage of HIV-1 replication without blocking viral adsorption. Antivir Chem Chemother. 2002;13:283-8.

29. Mazzanti G, Battinelli L, Pompeo C. Inhibitory activity of Melissa officinalis L. extraction herpes simplex virus type 2 replication. Nat Prod Res. 2008;22: 1433-40.

30. Meneses R, Ocazionez RE, Martínez JR, Stashenko EE. Inhibitory effect of essential oils obtained from plants grown in Colombia on yellow fever virus replication in vitro. Ann Clin Microbiol Antimicrob. 2009;8:8.

31. Schnitzler $P$, Koch C, Reichling J. Susceptibility of drug-resistant clinical herpes simplex virus type 1 strains to essential oils of ginger, thyme, hyssop, and sandalwood. Antimicrob Agents Chemother. 2007;51(5):1859-62.

32. Yamasaki K, Nakano M, Kawahata T, Mori H, Otake T, Ueba N, Oishi I, Inami R, Yamane M, Nakamura M, Murata H, Nakanishi T. Anti-HIV-1 activity of herbs in Labiatae. Biol Pharm Bull. 1998;21(8):829-33.

33. Geuenich S, Goffinet $C$, Venzke S, Nolkemper S, Baumann I, Plinkert P, Reichling J, Keppler OT. Aqueous extracts from peppermint, sage and 
lemon balm leaves display potent anti-HIV-1 activity by increasing the virion density. Retrovirology. 2008;5:27.

34. Zhang XL, Guo YS, Wang CH, Li GQ, Xu JJ, Chung HY, Ye WC, Li YL, Wang GC. Phenolic compounds from Origanum vulgare and their antioxidant and antiviral activities. Food Chem. 2014;152:300-6.

35. Usha V, Suriyavathana M. Free radical scavenging activity of ethanolic extract of Desmodium gangeticum. JACME. 2012;2:36-42.

36. Ligor M, Stankevičius M, Wenda-Piesik A, Obelevičius K, Ragažinskiene $\mathrm{O}$, Stanius Ž, Maruška A, Buszewski B. Comparative gas chromatographic-mass spectrometric evaluation of hop (Humulus lupulus L.) essential oils and extracts obtained using different sample preparation methods. Food Anal Methods. 2013;7:1433-42.

37. Kaškonienè $\mathrm{V}$, Kaškonas $\mathrm{P}$, Jalinskaitè $\mathrm{M}$, Maruška A. Chemical composition and chemometric analysis of variation in essential oils of Calendula officinalis L. during vegetation stages. Chromatographia. 2011;73(1):163-9.

38. Mosmann T. Rapid colorimetric assay for cellular growth and survival: application to proliferation and cytotoxicity assays. J Immunol Methods. 1983;65(1-2):55-63.

39. Meir R, Maharat O, Farnushi Y, Simanov L. Development of a real-time TaqMan RT-PCR assay for the detection of infectious bronchitis virus in chickens, and comparison of RT-PCR and virus isolation. J Virol Methods. 2010;163(2):190-4.

\section{Publisher's Note}

Springer Nature remains neutral with regard to jurisdictional claims in published maps and institutional affiliations.

Ready to submit your research? Choose BMC and benefit from:

- fast, convenient online submission

- thorough peer review by experienced researchers in your field

- rapid publication on acceptance

- support for research data, including large and complex data types

- gold Open Access which fosters wider collaboration and increased citations

- maximum visibility for your research: over $100 \mathrm{M}$ website views per year

At $\mathrm{BMC}$, research is always in progress.

Learn more biomedcentral.com/submissions 